\title{
Article
}

\section{Explorations in anatomy: the remains from Royal London Hospital}

Morris, James

Available at http://clok.uclan.ac.uk/10707/

Morris, James ORCID: 0000-0002-5756-0362 (2014) Explorations in anatomy: the remains from Royal London Hospital. Anthropozoologica, 49 (1). pp. 109120. ISSN 0761-3032

It is advisable to refer to the publisher's version if you intend to cite from the work. http://dx.doi.org/10.5252/az2014n1a08

For more information about UCLan's research in this area go to

http://www.uclan.ac.uk/researchgroups/ and search for < name of research Group>.

For information about Research generally at UCLan please go to http://www.uclan.ac.uk/research/

All outputs in CLoK are protected by Intellectual Property Rights law, including Copyright law. Copyright, IPR and Moral Rights for the works on this site are retained by the individual authors and/or other copyright owners. Terms and conditions for use of this material are defined in the policies page.

\section{CLoK}

Central Lancashire online Knowledge www.clok.uclan.ac.uk

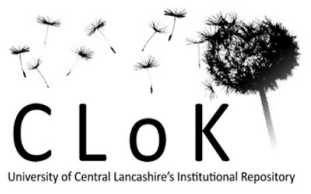




\title{
Explorations in anatomy: the remains from Royal London Hospital
}

\author{
James MORRIS \\ School of Forensic and Investigative Sciences, \\ University of Central Lancashire, \\ Preston, PR1 2HE (United Kingdom) \\ jmorris9@uclan.ac.uk
}

\section{KEY WORDS \\ Hospital, anatomy teaching, animal dissection, monkey, tortoise.}

\section{MOTS CLÉS}

Hôpital,

l'enseignement anatomie, la dissection des animaux,

Morris J. 2014. - Explorations in anatomy: the remains from Royal London Hospital. Anthorpozoologica 49 (1): xx-xx.

\begin{abstract}
This paper considers the faunal remains from recent excavations at the Royal London Hospital. The remains date to the beginning of the $19^{\text {th }}$ century and offer an insight into the life of the hospital's patients and practices of the attached medical school. Many of the animal remains consist of partially dissected skeletons, including the unique finds of Hermann's tortoise (Testudo hermanni) and Cercopithecus monkey. The hospital diet and developments in comparative anatomy are discussed by integrating the results with documentary research. They show that zooarchaeological study of later post-medieval material can significantly enhance our understanding of the exploitation of animals in this period
\end{abstract}

\section{RÉSUMÉ}

Explorations anatomiques: les restes du Royal London Hospital.

Cet article porte sur l'étude les restes fauniques recueillis lors d'une fouille récente du Royal London Hospital. Les restes datent du début du 19e siècle et offrent un aperçu de la vie des patients de l'hôpital, ainsi que des cliniques de l'école médicale qui lui étaient attachées. Plusieurs restes fauniques proviennent de squelettes partiellement disséqués, y compris ceux de tortue d'Hermann (Testudo hermanni) et de singes cercopithèques, qui constituent des trouvailles uniques. L'alimentation au sein de l'hôpital ainsi que les développements en anatomie comparative sont discutés par une intégration des résultats de l'analyse faunique avec ceux d'une recherche documentaire. Ils démontrent que l'analyse zooarchéologique de matériels de l'époque post-médiévale tardive peut améliorer de manière significative notre compréhension de l'exploitation des animaux au cours de cette période. 


\section{INTRODUCTION}

In the last two decades, the study of British postmedieval remains has grown and developed in status, yet zooarchaeological studies of the period have lagged behind (Murphy 2007; Thomas 2009). Some of the key reasons for this (e.g. the truncation of deposits and problems of residuality) will be familiar to many archaeologists studying this time period. There is also the low perceived value of faunal data in a 'well-documented' period, a lack of coverage in regional research agendas/ frameworks and on multi-period sites, which post-medieval sites invariably are, zooarchaeologists' time is often 'saved' for material from earlier periods. However, this lack of engagement with post-medieval faunal remains comes from both archaeologists and zooarchaeologists alike. Yet faunal remains have the potential to advance our knowledge regarding the dynamic changes in human-animal relationships that were witnessed in the later post-medieval period; changes that have contributed to the shaping of current attitudes to animals.

In 2006 and 2007 a series of excavations were carried out by Museum of London Archaeology (MOLA) in advance of building redevelopment at the Royal London Hospital, Whitechapel, East London. The excavations revealed archaeological features relating to the construction and use of the Hospital in the early $19^{\text {th }}$ century. As well as a large number of human remains, the excavations recovered a faunal assemblage, which affords unique insight into the hospital's practices, both in terms of the patients' diet and developments in comparative anatomy. The assemblage also sheds light on the nature of animal exploitation at the time.

\section{HISTORICAL AND ARCHAEOLOGICAL CONTEXT}

The London Hospital was founded in 1740 and was originally located in Moorfields, becoming the 'Royal London Hospital' in 1990. In 1752 construction of a three storey U-shaped building began at the current site, on previously undeveloped agricultural land. The central block of the hospital opened in 1759, with the east and west wings opening in 1775 and 1778 respectively. By 1830 the majority of the land around the hospital had been built upon, although a plot of land to the south of the hospital was kept free of buildings (Clark-Kennedy 1962: 231).

From the outset, the hospital was set up and run as a charitable institution. With a donation of one guinea per year, an individual could apply to become a governor of the hospital which gave access to the facilities and the right to recommend patients for treatment. Many local businesses also paid to enable their workers to use the hospital. For example, the East India Company sent an annual donation in recognition of the services rendered to its seamen (Clark-Kennedy 1962: 158). In addition, the hospital acted as an accident and emergency department, accepting patients with acute illness or physical injury if it was necessary for the preservation of the life of the patient. The decision to accept these patients was the responsibility of the hospital's medical staff, although it sometimes led to conflict with the governors, who wished to ensure enough room was left in the hospital for their recommended patients (Fowler \& Powers 2012a).

In 1785 Sir William Blizard, a very important figure in the history of the London Hospital, and Dr James Maddocks opened the hospital's anatomy college, the first in the country to be hospital-based. It was located within the Grocer's wing, the eastern wing of the hospital. The college ran on an informal basis until 1831 when the association, "Lecturers on and Teachers of Medicine, Surgery and Anatomy and other Sciences connected therewith at the Theatre attached to the London Hospital" was formed. This became the Medical Council of the London Hospital School in 1847 and in 1852 the school moved to a new site (Fowler \& Powers 2012b).

The archaeological work took place in two areas; area B was located within the hospital's main burial ground that was officially in use from 1840 to 1854 , although documentary evidence of later use does exist (Basil-Holmes 1896). Excavations 


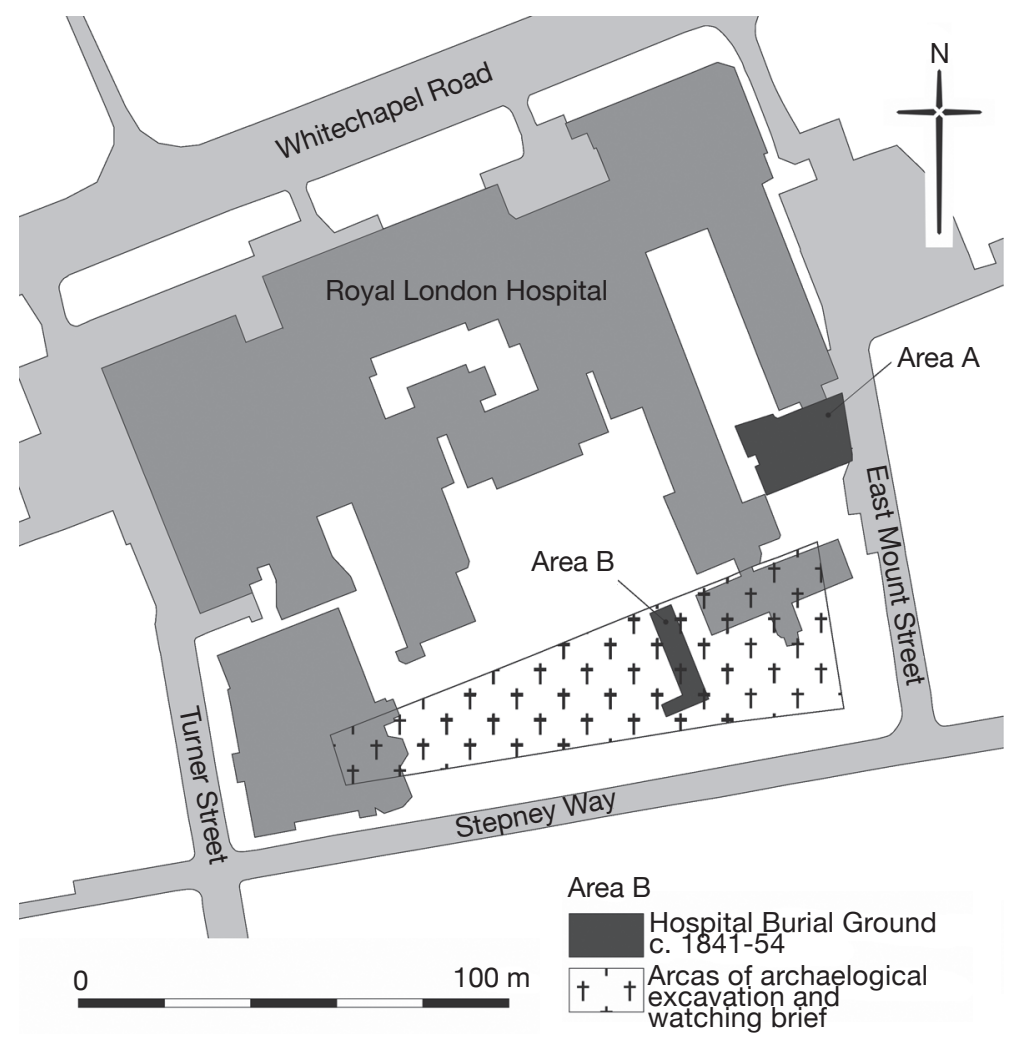

Fig. 1. - Map showing the areas of archaeological excavation at the Royal London Hospital. Drawn by Tracy Wellman, copyright MOLA.

also took place in area A which is located to the south of the Grocer's wing (Fig. 1). The faunal remains discussed here come from this area and all were recovered by hand during the excavation. A preliminary account of the remains can be found in Morris et al. (2011), a full account of all the faunal remains from the site is in Morris 2012.

The main archaeological features discovered in area A were 272 human graves, of which 103 consisted of coffins or boxes containing the dissected body parts of more than one individual. A large proportion, $87 \%$ (2292), of the faunal remains were also recovered from these coffins (Table 1), intermingled with the human remains. Before excavations started, area A was not known as an area of official hospital burials. It appears to have been used for burials from the 1820s. A contemporary account mentions that the burial ground at this time lay to the south of the medical college, in the area to the east of the east wing of the hospital (Millard 1825: 25), remaining in use no later than 1840 when the southern burial ground was established (Fowler and Powers 2012a).

\section{THE FAUNAL ASSEMBLAGE}

The excavations in area A produced a faunal assemblage of 2,538 fragments. Preservation on the site was excellent and it was possible to identify $86 \%(2,200)$ of the assemblage to both element and taxon. Overall, domestic mammals dominate with dog, sheep/goat and cow the most common taxa (Table 1). A 
TABLE 8.1 - Numbers of specimens from graves and disturbed contexts in area A

\begin{tabular}{|c|c|c|c|}
\hline Taxon & Graves & Disturbed contexts & Tota \\
\hline Cattle & 127 & 65 & 192 \\
\hline Sheep/goat & 239 & 135 & 374 \\
\hline Goat & 1 & & 1 \\
\hline Pig & 35 & 4 & 39 \\
\hline Horse & 12 & 3 & 15 \\
\hline Dog & 758 & 29 & 787 \\
\hline Cat & 72 & 19 & 91 \\
\hline Hare & 3 & & 3 \\
\hline Rabbit & 328 & 2 & 330 \\
\hline Hedgehog & 37 & & 37 \\
\hline Guinea pig & & 1 & 1 \\
\hline Monkey,Cercopithecus & 118 & 1 & 119 \\
\hline Monkey, Unidentified & 3 & & 3 \\
\hline Rat (black) & 3 & 1 & 4 \\
\hline Domestic fowl & 16 & 4 & 20 \\
\hline Goose & 4 & 1 & 5 \\
\hline Duck & 1 & & 1 \\
\hline Turkey & & 3 & 3 \\
\hline Small passerine & 1 & & 1 \\
\hline Gadid & 2 & & 2 \\
\hline Conger eel & 12 & & 12 \\
\hline Plaice/flounder & 1 & & 1 \\
\hline Plaice & 39 & & 39 \\
\hline Mackerel & 1 & & 1 \\
\hline Frog/toad & 1 & & 1 \\
\hline Tortoise & 19 & & 19 \\
\hline Cattle-sized & 166 & 48 & 214 \\
\hline Sheep-sized & 183 & 28 & 211 \\
\hline Unidentified mammal & 4 & & 4 \\
\hline Unidentified bird & 5 & 1 & 6 \\
\hline Unidentified fish & 2 & & 2 \\
\hline Total & 2193 & 345 & 2538 \\
\hline
\end{tabular}

number of non-native animals are also present, including the remains of monkey, guinea pig and tortoise. The remains in area $\mathrm{A}$ were recovered from two main feature types, either the grave and coffin contexts, often comingled with the human remains, or from the disturbed layers above the inhumations.

A large proportion, 55\% (1203), of the faunal remains from the grave contexts consisted of associated bone groups, identified in post-excavation; associated bone groups are remains from the same individual animal, the term is used rather than burial, to remove any associated connotations (Morris 2011: 12). Of the 758 dog elements from these contexts, 689 derive from 12 individual animals. As- sociated bone groups of cattle, sheep/goat, horse, cat, monkey, rabbit, hedgehog, tortoise and plaice are also present. Due to the comingled nature of the human and animal bone material it is not known whether any of them were deposited in articulation. This is further hindered by the fact that many of the remains were recovered from coffin stacks which had decayed resulting in slumping and further commingling.

The rest of the remains come from makeup overlaying the burials. These contexts contain a mixture of material dating to the second and third quarters of the $19^{\text {th }}$ century that includes redeposited material from the inhumations along with more general hospital refuse. 
TABLE 8.2 - Summary of the advised 'common diet' for patients in the late $1700 \mathrm{~s}$

\begin{tabular}{llll}
\hline & Breakfast & Dinner & Supper \\
\hline Sunday & Milk pottage & Boiled mutton & Broth \\
Monday & Water gruel & Pudding baked or boiled & Milk pottage \\
Tuesday & Butter or cheese & Boiled beef & Broth \\
Wednesday & Milk pottage & Pudding baked or boiled & Butter or cheese \\
Thursday & Water gruel & Boiled mutton & Broth \\
Friday & Butter or cheese & Boiled beef & Broth \\
Saturday & Water gruel & Rice milk & Butter or cheese \\
\hline
\end{tabular}

\section{HOSPITAL DIET}

The hospital had its own kitchens, one of which was located in the buildings close to excavation area A. Records held in the hospital archive indicate a variety of diets were prescribed to in-patients depending on their circumstances. Table 2 shows the recommended 'common diet' for patients in the late 1700s. Those put on 'the extraordinary diet' were to have veal instead of beef on Tuesday and fish on Monday and Friday. A 'middle diet', with a cut in the beer and meat ration and 'panado' (stale bread boiled in water) for breakfast and a 'low diet' with no beer or meat and a cut bread ration, were also used. Jewish patients were allowed two and a half pence allowance per day in lieu of meat and broth, but got bread and beer like the other patients. In 1788 John Howard, a governor of the hospital, visited and published his findings. He stated:

'The patients' diet I disapprove of; as, their common diet is 8 oz. of meat every day for dinner; and for supper broth six days a week. No vegetables, and only $12 \mathrm{oz}$. of bread a day. The Middle Diet is 4 oz. of meat every day for dinner; for supper, a pint of broth or panado. No vegetables and only 8 oz. of bread. The breakfast for every day, of those patients that are on common diet is one pint of milk pottage or water gruel. Those on the middle diet one pint of panado or water gruel. The drink of the former is three pints of beer in summer and 1 quart in winter. Of the latter one pint of beer every day' (Howard 1791: 131).

However, opinions regarding the diet of patients varied. In 1803, with finances poor, the house committee appointed a sub-committee to look into increased expenditure. They reported that 'unauthorised persons' had departed from the diet 'in the direction of extravagance'. That the increased expenditure was:

'due in good measure to departure from the plain and obvious directions of the diet, lately adjusted and ordered several years ago when the daily food of the labouring class was as substantial as required now, and which in its respective ratio was sufficient for sustenation with all due regard to temperance and economy' (quoted in Clark-Kennedy 1962: 198).

It was also suggested that: the amount of lean meat used to make broth was reduced; potatoes be used instead of bread to make poultices; patients were not to be given bread until the previous days ration was consumed; meatless 'banyan' days be introduced; and that there was no need to give food to patients when they were 'suffering ye agonies of pain or sinking under dejection as almost to loath even the approach of food and can neither take or digest it' (Clark-Kennedy 1962: 199).

The food, along with other provisions to the hospital, was supplied by local contractors. The hospital house committee reports several times that the provisions were usually 'good of their kind', but unsurprisingly given the above information, there are accounts that visitors and patients complained about the quality of the food and drink. These objections included that the meat supplied contained 'too much bone' and on one occasion the mutton was 'the worst' the visitor had ever seen 'in any market' (Clark-Kennedy 1962: 152). The austerity measures implemented at the beginning of the 1800s diminished by the 1820s. At this point the Samaritan Society had, for six months, been paying for extra food for the 


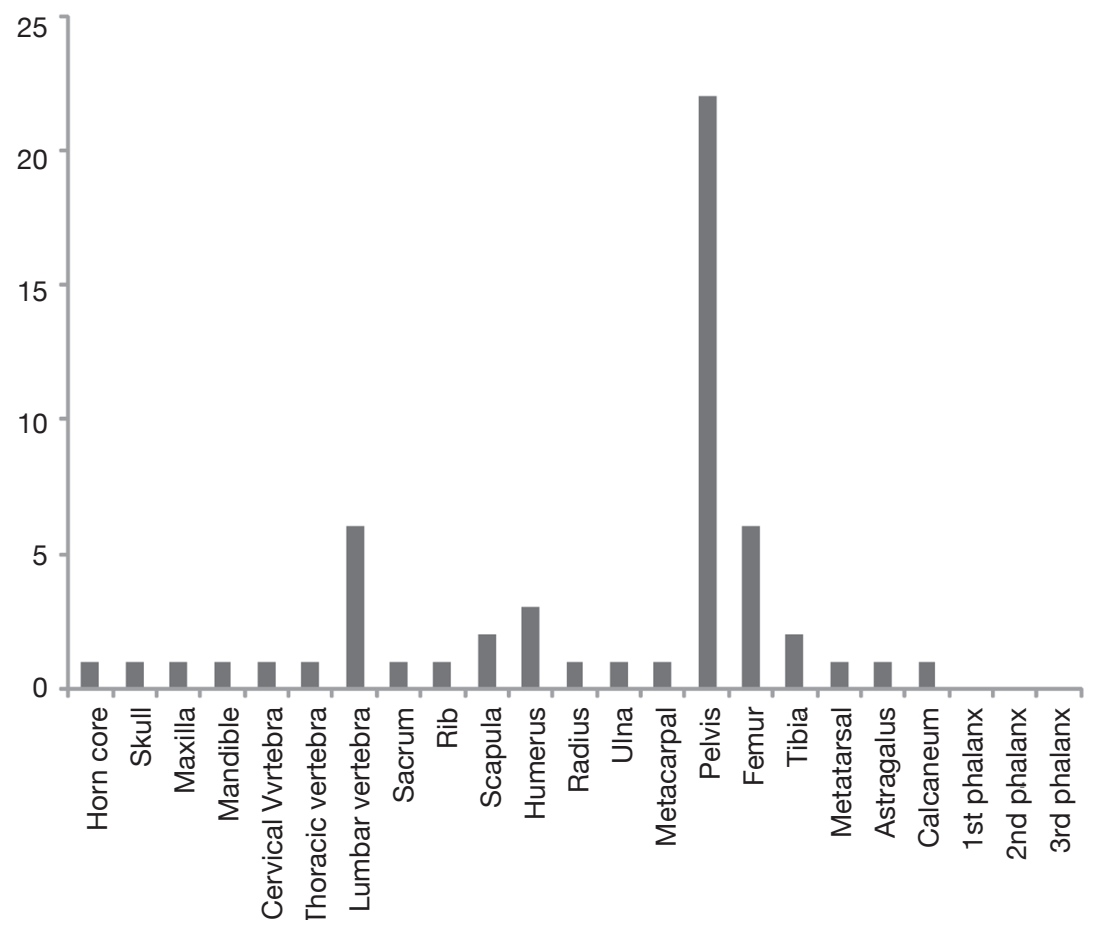

Fig. 2. - Graph showing the MNE count of sheep/goat elements recovered from disturbed contexts.

sickest patients, although the records indicate that they thought this should really be the hospital's responsibility. At this time the 'banyan' days were abolished and the meat ration increased to eight ounces, free of bone when dressed. However, there were still ongoing problems with the meat supply. The committee records for 1821 indicate that the lowest costed tenders for supplies were accepted including meat (beef and mutton, shins of beef and ox heads) from a Mr Lintoff. But the meat supplied was of such poor quality, Mr Lintoff's tender for 1822 was rejected, even though it remained the cheapest (LH/A/5/17 p142).

Given the excellent documentary information available for patient diet the challenge is to try and integrate this with the zooarchaeological evidence. The majority of the faunal data relating to the hospital diet comes from the disturbed contexts, although some 'rubbish' also appears to have become incorporated into grave backfill. The animal bones do indicate that the meat brought to the hospital came as prepared joints and cuts. For example, pelves, followed by femora and lumbar vertebrae are the most common sheep/ goat elements from the disturbed layers, for both NISP (Number of Identified Specimens) and MNE (Minimum Number of Elements) counts (Fig.2). The majority of long bone, pelvis and vertebra elements from these contexts are butchered and the hospital appears to have been supplied with certain cuts of meat. The high percentage of sheep/goat pelvis and lumber vertebra would suggest that a mutton saddle, combining the 'best' and 'chump' end of the loin, was often supplied (Rixson 2000: 245).

The hospital kitchens supplied meals for both patients and staff of the hospital, many of whom lived on site. It is therefore possible some of the more 'expensive' meats represent staff rather than patient meals. A small number of pig femora and metapodials are present, with evidence of butchery. Some poultry also appears to have been consumed. 
The majority are from domestic fowl, but there are also elements of goose and turkey present. The turkey remains consist of three tibiotarsi from the disturbed contexts. The turkey elements could tie in with documentary accounts of Christmas day at the hospital in the late 1800s. Turkeys were carved by the residents in the lobbies at dinner time and a midnight supper was served to the scrubbers. It is also possible that the pig, poultry and fish remains (cod and conger eel) represent occasional patient consumption events. Although patient diet was usually strictly controlled, the rules were occasionally bent to accommodate individual needs. For example, from the records of the late 1700s there is an account of a William Burridge, whose broken leg became infected and he lost his appetite. The surgeon ordered 'chicken, fish or anything else he could eat, and large nosegays to prevent him being affected by the stench of his leg' (Clark-Kennedy 1962: 91).

\section{EXPLORATIONS IN ANATOMY}

As discussed above, the majority of the faunal assemblage was recovered in association with human remains. Almost half of the graves contained human body parts from more than one individual and many showed signs of dissection. The graveyard in area A spans a period of time that witnessed the introduction of the 1832 Anatomy Act. Before this edict, only individuals condemned to death and dissection by the court could be legally supplied. Thus, an 1828 report from the Select Committee on Anatomy noted that students in anatomy schools in London had access to less than one cadaver per student (Bailey 1896: 70). The supply from legitimate means was supplemented by the activities of resurrectionists. Although the London's anatomy school was not meant to use hospital patients, the location of the burial ground in area $A$ proved to be very convenient as 'the dissecting room has a door opening into the burial ground of the Institution, where, those who have died in the Hospital are sometimes interred for the sake of appearances, and whence they may be easily transferred to the dissecting room, as occasion may require'(Millard 1825: 25).

The difficulty and problems with the legality of securing human remains meant that animals were often used. In the $18^{\text {th }}$ and $19^{\text {th }}$ centuries, animals were examined and experimented upon as part of public anatomy 'shows' (Guerrini 2004). This was also the time of the 'polite' gentleman scientist (Walters 1997), although the practices of anatomy were anything but polite, with individuals such as Samuel Johnson, William Stukeley and John Hunter interested in many aspects of natural philosophy. William Blizard, the founder of the London's medical college was himself a Fellow of the Royal Society, president of the Anatomy Society, Fellow of the Royal Societies of Edinburgh and Gottingen and a Fellow of the Society of Antiquaries of London (Auden 1978). However, for those individuals whose primary interests were anthropocentric, the greatest use of comparative anatomy was to throw light upon human anatomy. Two contemporaries of Blizard wrote:

'In collecting evidence upon any medical subject, there are but three sources from which we can hope to obtain it; from observation on the living subject from examination of the dead; and from experiments upon living animals. By the first, we learn the history of disease; by the second, its real nature, so far as it can be certainly known; and by experiments upon living animals, we ascertain the processes resorted to by nature for restoring parts which have sustained injuries, and then apply that knowledge to accidents in man' (Cooper and Travers 1818: 112)

During the period the hospital's anatomy collage was operating, it was standard practice for animal dissections and vivisections to be used alongside human cadavers (Kalof 2007: 124; Lansbury 1985). Faunal remains from the anatomy school were identified by their composition and unusual taphonomic markers such as scalpel marks and their frequent deposition as associated bone groups (Table 3 ). These varied from complete specimens, such as the complete female dog from one grave [426], to the partial remains of other animals. From the remains re- 
TABLE 8.3 - Summary of the associated bone groups and exotic taxa recovered from area A;

\begin{tabular}{|c|c|c|c|}
\hline Context & Context type & Species & Description \\
\hline 100 & Disturbed layer & Cat & Pelvis and femur with copper wire \\
\hline 111 & Grave & Monkey & Two first metacarpals, juvenile, from different monkeys \\
\hline \multirow[t]{2}{*}{164} & Grave & Pig & Partial infant, hind elements \\
\hline & Grave & Dog & $\begin{array}{l}\text { Almost complete adult male, mandibles and some foot ele- } \\
\text { ments missing. pathology on hind limb }\end{array}$ \\
\hline 192 & Grave & Dog & Partial adult head and body elements \\
\hline 201 & Grave & Cow & Partial neonate, head and vertebral elements \\
\hline 210 & Grave & Horse & Partial adult, head and vertebral elements \\
\hline 213 & Grave & Rabbit & Partial head and front limbs, very large \\
\hline \multirow[t]{2}{*}{229} & Grave & Hedgehog & Almost complete adult, feet missing \\
\hline & & Tortoise & Partial Hermann's, limb bones, no carapace present \\
\hline 231 & Grave & Plaice & Complete \\
\hline 243 & Grave & Dog & Partial adult head and forelimb elements \\
\hline \multirow[t]{2}{*}{262} & Grave & Dog & Partial, cervical vertebra \\
\hline & & Cow & Adult skull with dissection marks \\
\hline \multirow[t]{3}{*}{272} & Grave & Monkey & $\begin{array}{l}\text { Possible Mona monkey, missing head and cervical vertebra, } \\
\text { juvenile }\end{array}$ \\
\hline & & Dog & Partial, infant, both hind limbs \\
\hline & & Dog & Partial, infant, head body, fore and hind limbs \\
\hline \multirow[t]{2}{*}{283} & Grave & Rabbit & Complete, juvenile large rabbit \\
\hline & & Dog & Partial male adult, hind elements \\
\hline 285 & Grave & Rabbit & Partial, hind limb elements \\
\hline 313 & Grave & Cat & Partial, juvenile, head and vertebral column \\
\hline 323 & Grave & Rabbit & Almost complete, adult, skull missing dissection marks \\
\hline 329 & Grave & Monkey & Fibula with dissection marks \\
\hline \multirow[t]{2}{*}{426} & Grave & Dog & Complete sub-adult, possibly female \\
\hline & & Rabbit & Partial adult, hind elements \\
\hline 431 & Grave & Sheep/Goat & Partial vertebral column \\
\hline 433 & Grave & Rabbit & Partial skull and forelimbs, very large \\
\hline \multirow[t]{2}{*}{457} & Grave & Cat & Two partial neonates, ribs, vertebra and long bones \\
\hline & & Tortoise & Humerus, unknown species but larger than Hermann's \\
\hline 468 & Grave & Dog & Partial, hind foot \\
\hline 479 & Grave & Dog & Partial adult, hind foot \\
\hline 515 & Grave & Dog & Partial sub-adult, body and hind limb elements \\
\hline 547 & Grave & Dog & Complete adult, possible female, dissection marks present \\
\hline 561 & Grave & Cat & Partial juvenile, body and forelimb elements \\
\hline 621 & Grave & Dog & Partial, adult, head, body and fore limbs \\
\hline 660 & Disturbed layer & $\begin{array}{l}\text { Monkey } \\
\text { Guinea Piq }\end{array}$ & $\begin{array}{l}\text { Cercopithecus, Humerus with possible dissection marks } \\
\text { Skull and maxilla }\end{array}$ \\
\hline
\end{tabular}

covered, both dogs and rabbits appear to be the most common animals utilised (Table 1 and 3). The dog remains include both juvenile and adult animals. The rabbit remains are particularly large and may represent the use of domestic 'lab' rabbits (Morris 2012).

Some graves also had more than one specimen placed within them. For example, grave [272] contained a fragmented cow skull with dissection marks, the almost complete skeleton of a monkey (Fig. 3), together with dissected human remains.
The monkey was identified as belonging to the genus Cercopithecus (old world monkeys) and possibly as a Mona monkey (Cercopithecus mona) which is found in western Africa. It represents the first archaeologically-recorded find of this species from the United Kingdom. Only the distal humerus epiphysis is fused, indicating the animal would have been between one and two years old (Bolter and Zihlman 2003; Washburn 1943). Pathology was noted on the skeleton with evidence of infection on the medial aspect of the right clavicle and a healed 
green stick fracture on the left fifth metacarpal. The skeleton is almost complete, with the exception of the skull, mandible and first six cervical vertebrae. The excellent bone preservation suggests that these elements had been removed prior to deposition, rather than destroyed by post-depositional factors.

A single monkey (Cercopithecus sp.) humerus was also recovered from a disturbed layer [660]. This element was also from a young animal as the proximal epiphysis was unfused. Two fine knife cuts were present on the anterior aspect of the shaft above the distal epiphysis. The fragmented skull and maxilla of a guinea pig (Cavia porcellus) were also recovered from the same layer. Single monkey fragments were also recovered from grave contexts. A distal left fibula shaft from an adult primate around the size of a Barbary ape was recovered from grave [331], along with dissected human remains. The fibula had fine horizontal cut marks that appear to have been made by a scalpel, running down the lateral aspect of the shaft. Two further monkey bones were recovered from grave [329]. These consisted of right-hand first metacarpals with the distal epiphyses unfused. It was only possible to identify the elements as non-hominid simian but they are morphologically distinct and appear to come from different species, both comparable in size to the Mona monkey. Their presence in the same deposit suggests that the remains may be from monkeys dissected in the same way and at the same time, perhaps part of a comparative study.

In this period, London had a very active docks bringing in trade from across the British Empire. The hospital records indicate that a number of inpatients worked at the docks and it might have been through these connections that exotic animals were obtained. Although Londoners may have been familiar with monkeys and other exotic animals since menageries were present at the Tower of London (becoming London Zoo in 1834) and at Exeter Exchange on the north side of the Strand, as well as animal dealers. When Richard Owen posthumously published John Hunter's (1861) 'Essays and Observations on Natural History, Anatomy, Physiology, Psychology and Geology' it was noted that of the 13,683 specimens in the Hunterian, some 500 different species were represented (Dobson 1962). Archaeologically, remains of Barbary ape (Macaca

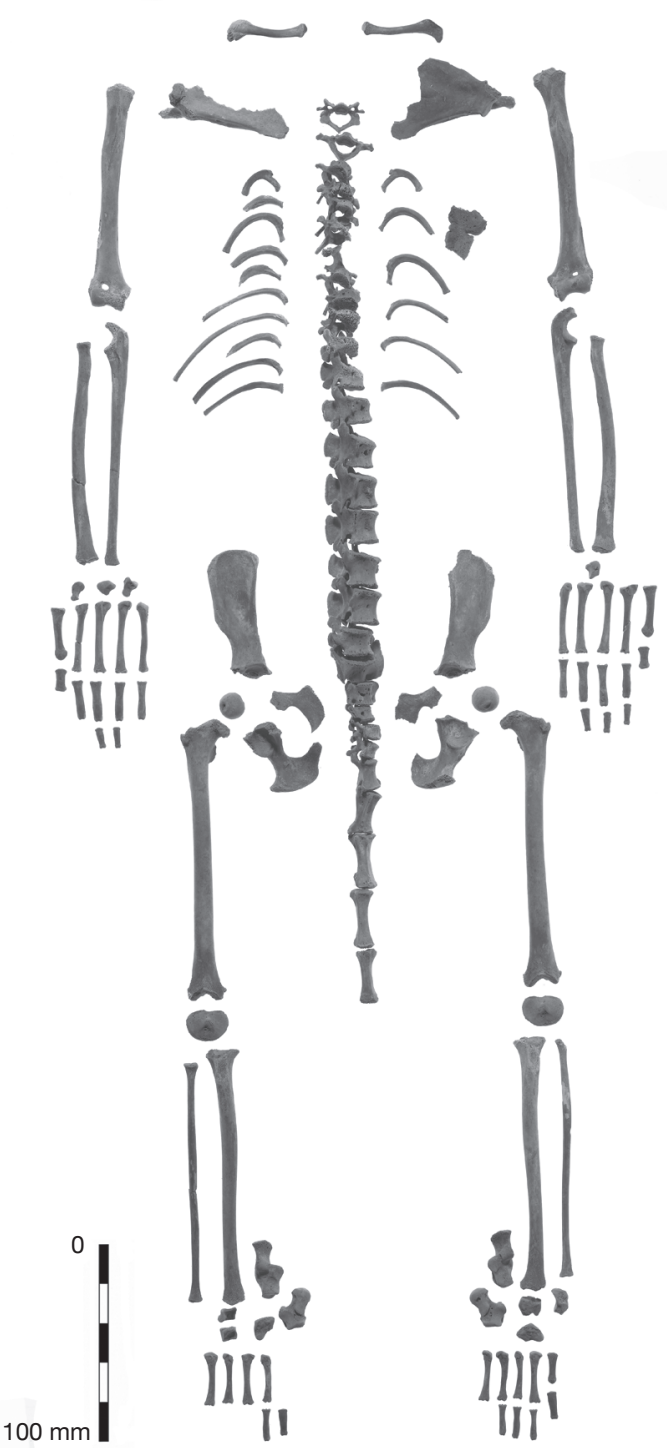

Fig. 3. - Mona monkey (Cercopithecus mona) skeleton from grave [272]. Photo by Andy Chopping, copyright MOLA

sylvanus) have been recovered from post-medieval London deposits (Pipe 1992), a South American capuchin monkey (Cebus nigrivittatus) jaw was recovered from a 17th-century layer at Brooks Wharf (Armitage 1981), turtles and terrapins from the 17th-century Limehouse site (Armitage et al. 2005), and remains of barbary lion (Panthera leo leo) and 


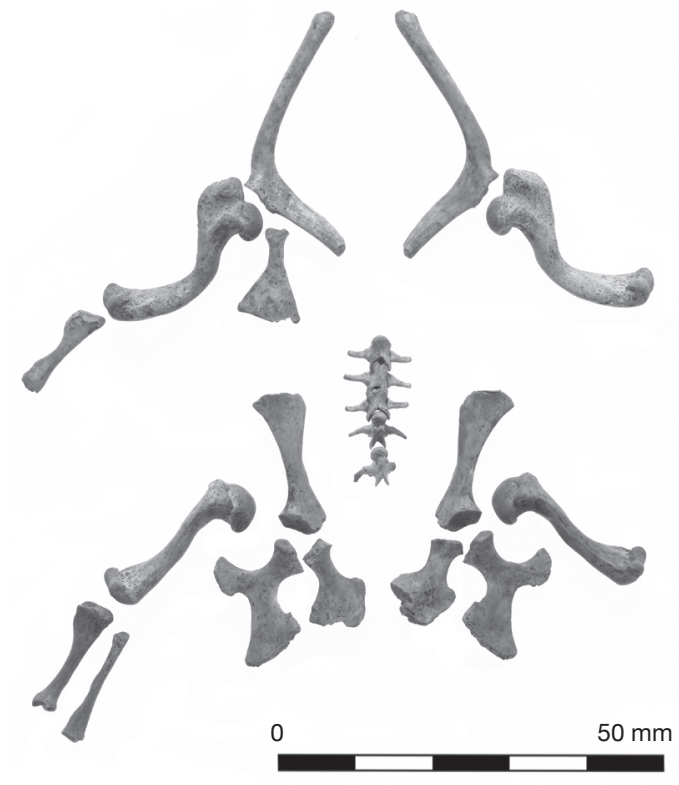

Fig. 4. - Partial Hermann's tortoise (Testudo hermanni) skeleton from grave [231]. Photo by Andy Chopping, copyright MOLA

leopard (Panthera pardus) were recovered from the Royal Menagerie at the Tower of London (O'Regan et al. 2006). The remains of North American racoon (Procyon lotor) and the radius of a manatee (Trichechus sp.) were also recovered from excavations at the Ashmolean Museum, Oxford (Hamilton-Dyer 2003) and guinea pig has been found at Hill Hall, Essex (Hamilton-Dyer 2009)

Cercopithecus monkeys and tortoises were certainly being used in comparative anatomy at this time. The skeleton of a Mono monkey is illustrated in Grant's (1841: 116) 'Outlines of Comparative Anatomy' as well as discussing the anatomy of tortoise and terrapins. John Hunter (1861: 10) discusses the anatomy of a Green Monkey (Chlorocebus sabaeus), the skull of which was kept as part of the Hunterian collection. A number of tortoise and terrapin species are discussed in the volume and it is often noted that the skulls and carapaces were kept as specimens in the Hunterian (1861: 357-364). It is possible that the missing elements from the monkey and tortoise associated bone groups were kept as part of the collection at the London's anatomy school. Evidence of such practises is shown by a cat pelvis and femur from one of the disturbed layers. These elements have holes drilled and copper wire still in-situ indicating that they were once part of a wired skeleton. Human remains have also been recovered with copper alloy wires and screws or iron pins. In 1831 Blizard donated his collection, which had been used in his lectures delivered at the London Hospital, to the Hunterian Museum. Amongst these and still present in the collection are: a preserved portion of cow's liver with lymphatic vessels injected with mercury (object number RCSHM/K 467.2); a cow's heart with abscess on the left ventricle (RSCPC/ $\mathrm{HC}$ 17.1); a pig foot with syndactyly (RSCPC/HC 18.2); a sheep foetus with extreme reduction of face and cranium (RSCPC/T 20D.14); and twin hares with cranio-thoraco-abdominal union.

Other non-native species include a partial skeleton of a Hermann's tortoise (Testudo hermanni) from grave [231] (Fig. 4). Dating to the early 1800s, this represents one of the current earliest archaeological finds of tortoise in the United Kingdom. Remains of the same genus have been recovered from Stafford Castle dating to the late 1800's (Thomas 2010). Although human attitudes to animals, live and dead, are slippery and complex (O'Connor 2007), the different life histories of these archaeologically-recovered tortoises show the range of exploitation and possibility attitudes to these animals. One being treated as an interesting anatomical specimen, the Stafford tortoise possibly being kept as a pet. A single tortoise humerus was also recovered from grave [457]. The element appears to be too large to be from any of the European species of tortoise and may from an African or Asian species (McCarthy pers. comm.)

It is interesting to note that the soft-tissue specimens preserved by Blizard derive mainly from commonlyconsumed domestic mammals, cattle, sheep and pig. Yet dog appears to be the most frequently used species from the faunal assemblage. There are examples of dissected sheep, cattle and horse elements and there is the possibility that elements from some of the more commonly consumed animals have been mistaken for 'kitchen waste'. However, dogs do appear to have been often used in dissections. They were the most common species from the excavation at the Ashmolean Museum, Oxford (Hamilton-Dyer 2003). There is also a record from the time that Sir Astley Cooper had a dissecting room at his house in St Mary Axe, 
London, where he kept up to 30 dogs, employing his butler to pay street children to round up strays (Wise 2004: 174). It is also highly likely that vivisection was being practiced on animals at the London Hospital. An insight into this is provided by a trial account from 1844 (Proceeding of the Old Bailey, t18440819). At the time Henry Leatherby was an assistant lecturer in the chemical department at the London Hospital. Testifying at the trial of a husband suspected of murdering his wife by prussic acid poisoning, he outlined how he had restored a poisoned cat in ten minutes and had given enough to a horse for it to have convulsions and be close to death before also reviving it.

Animals would have certainly played an important part in the anatomy teaching at the London Hospital. One of the aspects the project team will investigate further is how similar the animal and human dissections were. Some practices have already been noted, for example, a dissected cow skull from grave [272] included the cutting of the petrous bone to display the structure of the inner cochlea; similar cuts are present on some of the dissected human remains.

\section{CONCLUSION}

Placing the faunal remains from the Royal London Hospital excavations within their historical context has highlighted the variety of ways animals were exploited in $19^{\text {th }}$-century London. Not only do they give an insight into attitudes of patient care with respect to dietary practices within the hospital, but they also inform on the development of anatomical studies and the medical profession. At present, the monkey and tortoise remains found at the London appear to be unique archaeological discoveries and signify the importance of London in the developing international trade in animals. The presence of these exotic animals along with the other dissected remains shows how intertwined comparative anatomy and medical teaching was at the time.

This paper concerned the placement of the faunal remains within a wider historical context. It has shown that the integration of zoological, archaeological and documentary information can help build a rich tapestry of information for this time period. It has also shown the value of allowing zooarchaeologists to in- vestigate assemblages from this time period. Although in general documentary sources are available regarding animal dissections and vivisections and records of the use of human cadavers exist for London, the extensive use of animals by the anatomy school is only highlighted by the zooarchaeological evidence.

\section{Acknowledgements}

The Royal London Hospital project is funded by Skanska and Barts and the Royal London NHS Trust. Thanks must also go to Johanna Vuolteenaho, the excavation staff and on-site osteologists without their detailed and professional work on a complex and difficult excavation this analysis would not have been possible. Natasha Powers, Louise Fowler, Don Walker and Nigel Jeffries are part of the MOLA team working on the project and supplied help and advice with this article. Tracy Wellman provided Figure 1 and Andy Chopping the photos for figures 3 and 4. Colin McCarthy and Louise Tomsett of the Natural History Museum assisted with the identification of the tortoise and monkey bones. I would like to thank Shelia Hamilton-Dyer for the Ashmolean and Hill Hall information, Richard Thomas for the help with references, organising a stimulating and entertaining ICAZ session and his patience as an editor. The two peer reviewers for their useful comments, helping to order my thoughts and Justine Biddle for her useful editing and support. All errors remain my own.

\section{REFERENCES}

Armitage P. 1981. - Jawbone of a South American monkey from Brooks Wharf, City of London. London Archaeologist 4: 262-270.

Armitage P., Arnold N. \& Meddens F. 2005. Note on the reptile remains. In D. Killock \& F. MedDens (eds), Pottery as plunder: a $17^{\text {th-century }}$ maritime site in Limehouse, London. Post-Medieval Archaeology 39: 81-2.

AUDEN R. R. 1978. - A Hunterian pupil: Sir William Blizard and The London Hospital. Annals of the Royal College of Surgeons of England 60: 345-349.

BAILEY J. B. 1896. - The Diary of a Resurrectionist 1811 1812, to which are added an account of the resurrection men in London and a short history of the passing of the Anatomy Act. Swan Sonnenschein \& Co., London. 
BasiL-Holmes I. M. 1896. — The London Burial Grounds: Notes on their History from the Earliest Times to the Present Day. MacMillan, London.

Bolter D. R. \& Zihlman A. L. 2003.- Morphometric analysis of growth and development in wild-collected vervet monkeys (Cercopithecus aethiops), with implications for growth patterns in Old World monkeys, apes and humans. Journal of Zoology 260: 99-110.

Clark-Kennedy A. E. 1962. - The London: a Study in the Voluntary Hospital System Vol 1, 1740-1840. Pitman Medical Publishing, London.

Cooper A. \& Travers B. 1818.- Surgical Essays Part 1. Cox and Son, London.

DOBSON J. 1962. - John Hunter's Animals. Journal of the History of Medicine and Allied Sciences 17: 479-486.

FOWLer L. \& POWERS N. 2012a - Patients, anatomists and resurrection men: archaeological evidence for anatomy teaching at the London Hospital in the early nineteenth-century, in P. MiTCHELl (ed), Anatomical Dissection in Enlightenment England and Beyond. Autopsy, Pathology and Display. Ashgate, Farnham: 77-94.

FOWLER L \& POWERS N. (EDS) 2012b. - Doctors, Dissection and Resurrection Men: excavations in the 19th-century burial ground of the London Hospital, 2006. Museum of London Archaeology Monograph Series 62, London.

GRANT R. E. 1841. - Outlines of Comparative Anatomy. Hippolyte Bailliere, London.

GUERRINI A. 2004. - Anatomists and entrepreneurs in early eighteenth-century London. Journal of the History of Medicine and Allied Sciences 59 (2): 219-239.

Hamilton-Dyer S. 2003. - Animal bone. In G. Hull (ed.), The excavation and analysis of an $18^{\text {th }}$-century deposit of anatomical remains and chemical apparatus from the rear of the first Ashmolean Museum (now The Museum of the History of Science), Broad Street, Oxford. Post-Medieval Archaeology 37: 16-19.

Hamilton-Dyer S. 2009. - Animal Bones. In P. Dury \& R. Simpson (eds), Hill Hall: A Singular House Devised by a Tudor Intellectual. Society of Antiquaries and English Heritage Monograph, London: 345-351

HOWARD J. 1791. - An Account of the Principal Lazarettos in Europe: with various papers relative to the plague, together with further observations on some foreign prisons and hospitals, and additional remarks on the present state of those in Great Britain and Ireland. Johnson, Reaily \& Cardell, London.

HuNTER J. 1861. - Essays and Observations on Natural History, Anatomy, Physiology, Psychology and Geology. John Van Voorst, London.

KALOF L. 2007. - Looking at Animals in Human History. Reaktion Books, London.

LANSBURY C. 1985. - The Old Brown Dog: Women, Workers and Vivisection in Edwardian England. University of Wisconsin Press, Madison.

Millard A. 1825. - An Account of the Circumstances At- tending the Imprisonment and Death of the Late William Millard. Ann Millard, London.

MORRIS J. 2011. - Investigating Animal Burials: Ritual, Mundane and Beyond. British Archaeological Reports, British Series 535, Oxford.

MORRIS J. 2012. - Vivisection and comparative anatomy. In L. Fowler \& N. Powers (eds), Doctors, Dissection and Resurrection Men: excavations in the 19thcentury burial ground of the London Hospital, 2006. Museum of London Archaeology Monograph Series 62, London: 160-165.

Morris J., Fowler L. \& POWERS N. 2011. — A hospital with connections: $19^{\text {th }}$-century exotic animal remains at the Royal London Hospital. Post-Medieval Archaeology 45: 367-373.

MURPHY E. 2007. - An overview of livestock husbandry and economic practices in the urban environments of post-medieval Ireland. In A. HorNing, R. Ó. BAOILL, C. Donnelly \& P. Logue (eds), The Post-Medieval Archaeology of Ireland 1550-1850. Wordwell, Bray: 371-391

O'CONNOR T. 2007. —Thinking about beastly bodies. In A. PLusKOWSKI (ed.), Breaking and Shaping Beastly Bodies: Animals as Material Culture in the Middle Ages. Oxbow, Oxford: 1-10

O'REgAn H., TuRnER A. \& SABIN R. 2006. — Medieval big cat remains from the royal menagerie at the Tower of London. International Journal of Osteoarchaeology 16: 385-394.

Old Bailey Proceedings. — August 1844 (t18440819).

PIPE, A. 1992. - A note on exotic animals from medieval and post-medieval London. Anthropozoologica 16: 189-191.

Rixson D. 2000. - The History of Meat Trading. Nottingham University Press, Nottingham.

Royal London Hospital ARCHIVE. - LH/A/5/17, Minute Book of the House Committee commencing 2nd January 1808 - 14th December 1924

ThOmas R. 2009. - Bones of contention: Why later post-medieval faunal assemblages in Britain matter. In A. Horning \& M. Palmer (eds), Crossing Paths or Sharing Tracks: Future Directions in the Archaeological Study of Post-1550 Britain and Ireland. Boydell and Brewer Ltd., Woodbridge: 133-148

Thomas R. 2010. - Translocated Testudinidae: the earliest archaeological evidence for land tortoise in Britain. Post-Medieval Archaeology 44 (1): 165-171.

Walters A. N. 1997. - Conversation pieces: science and politeness in eighteenth-century England. History of Science 35: 121-154.

WASHBURN S. L. 1943. - The sequence of epiphyseal union in Old World monkeys. American Journal of Anatomy 72: 339-360.

Wise S. 2004. - The Italian Boy: Murder and GraveRobbery in 1830s London. Pimlico, London. 